\title{
High- and low-affinity phosphate uptake and its effect on phytoplankton dominance in a phosphate-depauperate lake
}

\author{
Matthew J. Prentice ${ }^{1, *}$, Kate R. O'Brien' ${ }^{\text {, David P. Hamilton }}{ }^{3}$, Michele A. Burford ${ }^{1}$ \\ ${ }^{1}$ Australian Rivers Institute, Griffith University, Nathan, Queensland 4111, Australia \\ ${ }^{2}$ School of Chemical Engineering, The University of Queensland, St Lucia, Queensland 4072, Australia \\ ${ }^{3}$ Centre for Biodiversity and Ecology Research, The University of Waikato, Private Bag 3105, Hamilton 3240, New Zealand
}

\begin{abstract}
Phosphorus (P) is an essential element for phytoplankton growth, and in recent years our understanding of $\mathrm{P}$ use based on kinetics has been overturned with new knowledge of the complexity of P utilization. However, much of this knowledge is based on culture studies with individual species. Our objective was to measure the effect of dissolved inorganic P (DIP) concentrations on DIP uptake rates by phytoplankton, in the context of seasonal phytoplankton succession in a large monomictic, DIP-depauperate lake. We demonstrated an inverse relationship between surface DIP concentration and DIP uptake rate, with substantially higher uptake rates occurring under thermally stratified, DIP-depauperate conditions. The combination of surface water DIP concentration and water temperature explained $50.3 \%$ of the variation in uptake rates. DIP concentration explained the majority of variation, with a concentration of $4.75 \mu \mathrm{g}$ DIP $\mathrm{l}^{-1}$ appearing to be a transition between low- and high-affinity uptake. Variability below $4.75 \mu \mathrm{g}$ DIP $\mathrm{l}^{-1}$ was further explained by water temperature. High-affinity DIP uptake was most common when Cyanobacteria dominated the phytoplankton assemblage. We validated our field results by conducting a DIP starvation study on an isolate of a dominant cyanobacterium, Cylindrospermopsis raciborskii. High-affinity uptake was demonstrated as the culture became progressively starved of P. Our findings indicate that rapid DIP scavenging via high-affinity uptake is advantageous under DIP-depauperate conditions during the summer-stratification period. It may also contribute to the switch from diatom/cryptophyte/chlorophyte dominance to cyanobacterial dominance in summer. This study also has implications for phytoplankton-nutrient models, which typically do not incorporate high-affinity $\mathrm{P}$ uptake.
\end{abstract}

KEY WORDS: Phosphorus limitation · Phosphorus dynamics · Phosphorus cycling · Cyanobacteria · Cylindrospermopsis raciborskii $\cdot$ Phytoplankton blooms $\cdot$ Seasonal succession

Resale or republication not permitted without written consent of the publisher

\section{INTRODUCTION}

Phosphorus (P) is an essential element for energy transfer, structural components, and growth of all organisms (Karl \& Tien 1992, Tanaka et al. 2004). In aquatic systems, eukaryotic algae and Cyanobacteria rely solely on the transport of $\mathrm{P}$ from water across the cell membrane and into the cell for growth and cell division (Jansson 1988). P is available in a variety of forms but only dissolved inorganic P (DIP), consisting of orthophosphate and polyphosphates, is considered to be immediately available for uptake (Thingstad et al. 1993). Acquisition of DIP is definable with kinetic constants like the half saturation constant (e.g. Hwang et al. 1998), maximum uptake velocity (e.g. Thingstad et al. 1993) and specific affinity (e.g. Tanaka et al. 2006).

In lakes and reservoirs, DIP concentrations may become substantially reduced (particularly in the surface mixed layer) during periods of thermal strati- 
fication (Tanaka et al. 2004). This stratification, typically driven by warmer summer temperatures, may in turn affect competition amongst phytoplankton assemblages (Thingstad et al. 1993). For a species to dominate under seasonally-depauperate DIP concentrations, it must possess a means to support some minimum basal cellular $\mathrm{P}$ requirement. Phytoplankton possess a variety of adaptations to enhance DIP uptake and storage. These include the ability to take up $\mathrm{P}$ during DIP-replete conditions and store it in excess of their immediate cellular requirements (e.g. as polyphosphate bodies; Cotner \& Wetzel 1992), the ability to produce enzymes which hydrolyze DIP from a variety of dissolved organic P (DOP) compounds (Vidal et al. 2003, Muñoz-Martín et al. 2011), and the use of a high-affinity DIP uptake system (also referred to as active or surge uptake; Jansson 1993, Aubriot \& Bonilla 2012).

High-affinity uptake is initiated when the concentration of extracellular P decreases to a concentration too low to cross the transmembrane electrochemical gradient into the cell via the constitutive low-affinity DIP inorganic transport (Pit) system (Jansson 1988, Vershinina \& Znamenskaya 2002). Under such Pdepauperate conditions, Pho regulon genes are induced, which encode and up-regulate high-affinity P-binding proteins, such as pstS and sphX, of the repressible DIP specific transport (Pst) system (Jansson et al. 1988, Vershinina \& Znamenskaya 2002, Orchard et al. 2009). These high-affinity binding proteins bind and transport DIP into the cell, enabling species to assimilate DIP at nanomolar levels (Aubriot \& Bonilla 2012). It has been suggested that the high-affinity uptake process may enable phytoplankton to exploit the heterogeneity of $\mathrm{P}$ supply associated with hydrodynamic processes and allow for growth under chronically or seasonally low DIP levels (Jansson 1993). In P-limited systems, high-affinity DIP uptake has been demonstrated in a few eukaryotic algae such as the coccolithophorid Emiliania huxleyi (Lohmann) Hay \& Mohler (Riegman et al. 2000) and the diatom Thalassiosira pseudonana (Dyhrman et al. 2012) as well as a range of Cyanobacteria including Anabaena (MuñozMartín et al. 2011), Anacystis (Wagner et al. 1995), Aphanizomenon (Bar-Yosef et al. 2010), Crocosphaera (Dyhrman \& Haley 2006), Cylindrospermopsis (Istvànovics et al. 2000), Microcystis (Harke et al. 2012), Prochlorococcus (Moore et al. 2005), Scenedesmus (Jansson 1993), Synechococcus (Donald et al. 1997, Ritchie et al. 2001) and Trichodesmium (Orchard et al. 2003, 2009). Possession of a high-affinity uptake system may provide these species with a competitive advantage over others in which the process is either absent or weakly developed (Istvànovics et al. 2000, Posselt et al. 2009).

Cyanobacteria possess a suite of adaptations that allows them to dominate in summer months (Paerl \& Huisman 2009). These adaptations include (but are not limited to) survival and growth under elevated temperatures via higher temperature optima (Robarts \& Zohary 1987, Coles \& Jones 2000), low irradiance via accessory photosynthetic pigments (Scheffer et al. 1997), and variable nutrient supply via nitrogen fixation and the aforementioned high-affinity nutrient uptake (Istvànovics et al. 2000, Dyhrman \& Haley 2006, Posselt et al. 2009). These adaptations can result in frequent, large scale summer algal blooms and an expanding geographical range for many cyanobacterial species around the world (Istvànovics et al. 2000, Paerl \& Huisman 2009, Posselt et al. 2009). This is of particular concern as many Cyanobacteria produce harmful toxins, including hepato-, neuroand cytotoxins. One toxin of major importance is cylindrospermopsin, an alkaloid hepatotoxin produced in several genera including Cylindrospermopsis raciborskii (Woloszynska) Seenaya \& Subbaraju (Bláha et al. 2009, Burford \& Davis 2011). In humans, cylindrospermopsin can cause necrotic injury to organs including the liver, kidneys, spleen, lungs, and intestine, as well as being a protein synthesis inhibitor and genotoxic (Bláha et al. 2009). With global temperatures expected to continue rising, so too is a potential increase in the geographical range and frequency and severity of toxic cyanobacterial blooms around the world (Wiedner et al. 2007, Paerl \& Huisman 2009, O'Neil et al. 2012).

High-affinity DIP uptake has mostly been studied with cultured cyanobacterial species responding to imposed P regimes (e.g. Jansson 1993, Wagner et al. 1995, Donald et al. 1997, Istvànovics et al. 2000, Ritchie et al. 2001), and to a lesser extent in natural phytoplankton assemblages (e.g. Aubriot et al. 2000, 2011, Tanaka et al. 2006). More recently, genes involved in producing high-affinity P-binding proteins for high-affinity uptake have been identified in a range of Cyanobacteria and some eukaryotic algae (Dyhrman \& Haley 2006, Orchard et al. 2009, BarYosef et al. 2010). This understanding at the molecular level, however, has not been well translated to an understanding at the ecological level. Accordingly, our objective was to determine the effect of DIP concentrations on phytoplankton DIP uptake rate, and how it relates to seasonal phytoplankton succession in a large monomictic, P-depauperate lake over a $1 \mathrm{yr}$ period. We predicted that as DIP became depleted, the phytoplankton assemblage would transition 
towards one with the ability to perform high-affinity uptake. To validate this prediction, we measured DIP uptake response in the dominant cyanobacterial species C. Raciborskii under P-starved conditions.

\section{MATERIALS AND METHODS}

\section{Field sampling}

\section{Study site}

Lake Wivenhoe $\left(27^{\circ} 24^{\prime} \mathrm{S}, 152^{\circ} 36^{\prime} \mathrm{E}\right)$ is a monomictic reservoir that undergoes thermal stratification in the austral summer, during the wet-summer months (mid-October to mid-April). The climate of the region is subtropical, with mean monthly rainfall of $75 \mathrm{~mm}$ in summer and $34 \mathrm{~mm}$ in winter (Burford \& O'Donohue 2006). Its watershed is $5716 \mathrm{~km}^{2}$, consisting of approximately $50 \%$ forested areas and $50 \%$ agricultural land used primarily for cattle grazing (Burford et al. 2007). Lake Wivenhoe has a water storage capacity of 1165000 megalitres (Ml), a mean depth of $10.8 \mathrm{~m}$ and covers an area of $107 \mathrm{~km}^{2}$. It receives input water from controlled releases at Somerset Reservoir and unregulated inputs from the Upper Brisbane River (Burford \& O'Donohue 2006). Diatoms and chlorophytes typically dominate by biovolume during isothermal conditions, while Cyanobacteria frequently dominate during stratified conditions, with the toxic nitrogen fixer $C$. raciborskii being the most dominant by biovolume (Burford \& O'Donohue 2006, Muhid 2011).

\section{Sample collection}

Four sites (i.e. locations) within Lake Wivenhoe were sampled monthly from February 2009 to January 2010. The sites were selected within the drowned river channel that forms a longitudinal transect along Lake Wivenhoe (Fig. 1). The sites were within 3 distinct sub-basins; Site 1 in the upstream-riverine zone, Sites 2 and 3 at either end of the midstream zone and Site 4 in the downstream-lacustrine zones near the dam wall, referred to as the 'basin' (Muhid 2011). Water depths at the sites varied during the study due to a substantial inflow event in mid-May 2009, when $\sim 200000 \mathrm{Ml}$ of water entered the lake in $1 \mathrm{wk}$, increasing the dam storage from 46 to $63 \%$ of full storage capacity and increasing the water level by $3 \mathrm{~m}$ (from 28 to $31 \mathrm{~m}$ at the dam wall) over a period of 1 wk. For 4 wk after this event, more frequent sampling was undertaken. The water level increased approximately $6 \mathrm{~m}$ over the $1 \mathrm{yr}$ study period. The maximum depth during this study was $17 \mathrm{~m}$ at Site 1, $20 \mathrm{~m}$ at Site 2, $27 \mathrm{~m}$ at Site 3 and $34 \mathrm{~m}$ at Site 4.

Profiles of physico-chemical parameters (temperature, oxygen, conductivity, $\mathrm{pH}$ ) were measured at each site using a calibrated SONDE (model no. 6920; Yellow Springs Instruments) profiling at $1 \mathrm{~m}$ depth intervals from 0 to $10 \mathrm{~m}$, and then at $2 \mathrm{~m}$ intervals to the bottom. Determination of thermocline depth was complicated due to daily intakes and outtakes from an adjacent hydro-electric power station (Splityard Creek), which altered the thermocline structure over short timeframes (Gibbes et al. 2009). As such, the thermocline depth was determined as the depth of the greatest change in temperature over change in depth $(\mathrm{d} T / \mathrm{d} z)>0.5^{\circ} \mathrm{C} \mathrm{m}^{-1}$, rather than conventional changes in depth (e.g. $0.25^{\circ} \mathrm{C} \mathrm{m}^{-1}$; Burford et al. 2007). Where $\mathrm{d} T / \mathrm{d} z>0.5^{\circ} \mathrm{C} \mathrm{m}^{-1}$ the system was considered stratified and when $<0.5^{\circ} \mathrm{C}$, isothermal. Similarly, thermocline strength was determined as the greatest change in temperature over change in depth $(\mathrm{d} T / \mathrm{d} z)>0.5^{\circ} \mathrm{C} \mathrm{m}^{-1}$. Secchi depth was recorded at the same time. Rainfall and dam volume data were recorded daily (Seqwater unpubl. data).

Water samples for DIP uptake incubations, phytoplankton counts (Site 4 only), and nutrient and chlorophyll a ( $\mathrm{chl}$ a) analyses were collected from the

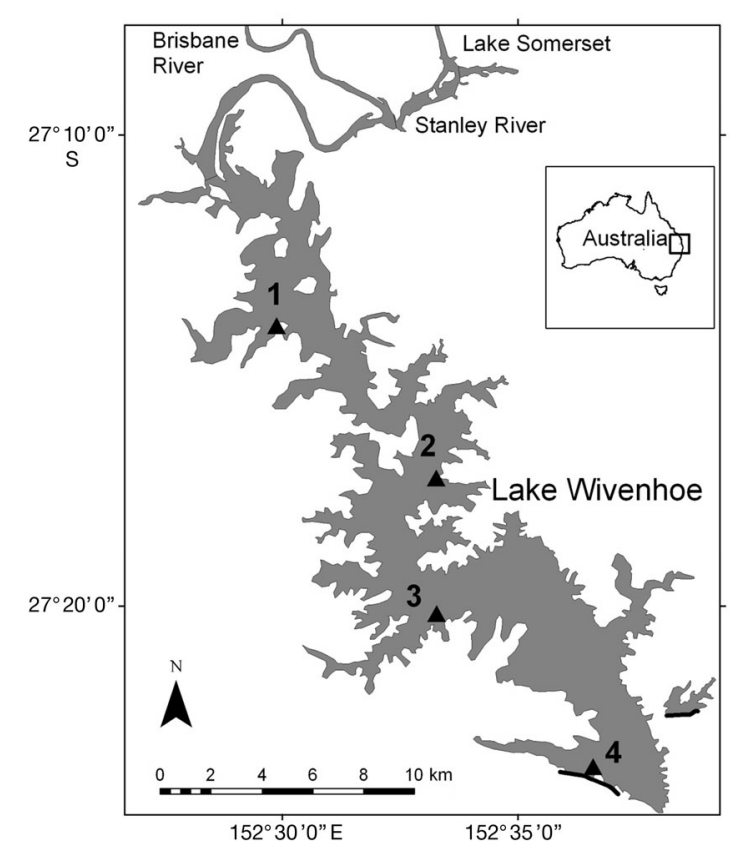

Fig. 1. Location of the 4 study sites in Lake Wivenhoe. Site 1 is nearest the inflows from the upper Brisbane River and Stanley River and Site 4 is nearest the dam wall (shown as a black line) 
surface waters using triplicate $3 \mathrm{~m}$ depth-integrated samples (5 cm diam.), and from the bottom $(1 \mathrm{~m}$ above the lake bottom up to a maximum of $30 \mathrm{~m}$ depth) using triplicate Van Dorn samples. Sub-samples for phytoplankton counts were fixed with Lugol's solution, then stored in the dark. Sub-samples for DIP uptake assays were kept cool and in the dark until returned to the laboratory where assays were undertaken. For chl $a$ and particulate P (PP) analyses, known volumes of water were filtered through pre-combusted glass fibre filters (GF-75; Advantec), and stored on ice for up to $6 \mathrm{~h}$ until frozen in the laboratory at $-80^{\circ} \mathrm{C}$. Unfiltered water samples were taken for total nitrogen (TN) and total P (TP) concentrations. For nitrate/nitrite $\left(\mathrm{NO}_{2}+\mathrm{NO}_{3}\right)$, ammonium $\left(\mathrm{NH}_{4}\right)$, DIP, total dissolved $\mathrm{N}$ (TDN) and total dissolved $\mathrm{P}$ (TDP) samples, water was filtered through $0.45 \mu \mathrm{m}$ filters (Millipore) in situ and stored on ice until frozen in the laboratory.

\section{Laboratory analyses}

In the laboratory, chl a filters were sonicated with a sonicator probe (Sonifier 450; Branson Ultrasonics) in $90 \%$ acetone, filtered through a $0.45 \mu \mathrm{m}$ glass fibre filter and analyzed spectrofluorometrically (Jeffrey \& Welschmeyer 1997). Phytoplankton were identified to species level where possible using phase-contrast microscopy, with cells enumerated and biovolume established from fixed samples using a Sedgewick Rafter counting chamber (Hötzel \& Croome 1999). A minimum of 30 fields was counted so as to include at least $90 \%$ of the species present (McAlice 1971). Biovolume was determined by measuring the dimensions of 30 cells for each species and calculating the average volume for each using formulae for geometric shapes most representative of the species. The average volume for each species was multiplied by its cell count, and the product of all species summed to produce a biovolume in $\mathrm{mm}^{3} \mathrm{ml}^{-1}$ (Hötzel \& Croome 1999). Cyanobacteria were counted at all sites, however the entire phytoplankton assemblage was counted at Sites 2 and 4 only.

Total and dissolved nutrient samples were analysed at a National Association of Testing Authorities (NATA) accredited (www.nata.com.au/nata/) laboratory. Concentrations of DIP, $\mathrm{NH}_{4}$ and $\mathrm{NO}_{2}+\mathrm{NO}_{3}$ were measured using standard colourimetric methods (APHA 1995) on filtered samples with a LACHAT 8000 Quick Chem flow injection analyzer (Lachat Instruments). Filtered samples for TDP and TDN were digested with persulphate (Ebina et al. 1983) and measured using standard colourimetric methods (APHA 1995). Phosphorus detection limits at the NATA accredited laboratory were $2 \mu \mathrm{g} \mathrm{l}^{-1}$ for filtered samples and $10 \mu \mathrm{g} \mathrm{l}^{-1}$ for unfiltered samples. Concentrations of DOP and DON were calculated as the difference between DIP and TDP, and $\mathrm{NH}_{4}+\mathrm{NO}_{2}+$ $\mathrm{NO}_{3}$ and TDN, respectively. Samples below defection limits were entered as half the detection limit, and removed from any analysis.

Uptake of $\mathrm{P}$ was measured according to Thingstad et al. (1993) and Tanaka et al. (2006). P uptake was estimated in the laboratory within a few hours of water collection by labelling three $500 \mathrm{ml}$ sub-samples of lake water with phosphorus-33 $\left({ }^{33} \mathrm{P}\right)$ in orthophosphoric acid (PerkinElmer). Samples were equilibrated at temperatures comparable to in situ water temperatures under fluorescent lights (Gro Light) at a light intensity of $\sim 220 \mu \mathrm{mol} \mathrm{m} \mathrm{m}^{-2} \mathrm{~s}^{-1}$. To measure DIP uptake, each replicate was spiked with $20 \mu$ of ${ }^{33} \mathrm{P}$ solution of known activity, made up in a dilution of 0.3 megabecquerel (MBq) ${ }^{33} \mathrm{P}$ in $500 \mu \mathrm{l}$ distilled water. A time course of sub-sampling and immediate filtration through $0.6 \mu \mathrm{m}$ pore size polycarbonate membrane filters (Sterlitech) was conducted using between 6 and 12 sub-samples over a period of $2 \mathrm{~min}$ to $4 \mathrm{~h}$, depending on expected turnover time (TT) (Tanaka et al. 2006); expected TT was determined by an expendable pilot replicate. Filters were then analyzed for radioactivity on a Liquid Scintillation Analyzer (Packard Tri-Carb 2100TR), along with standards of known concentration, quenching standards and blanks to correct samples for radioactive decay and background radioactivity (Hudson \& Taylor 1996).

The TT for DIP was calculated as:

$$
T=\frac{[P]}{U_{R}}
$$

where $T$ is the DIP TT $\left(\mathrm{h}^{-1}\right),[P]$ is the ambient concentration of DIP in the water prior to the assay ( $\mu \mathrm{g}$ $\mathrm{l}^{-1}$ ) and $U_{R}$ is the DIP uptake rate $\left(\mu \mathrm{g}\right.$ DIP $\left.\mathrm{l}^{-1} \mathrm{~h}^{-1}\right)$.

Measured DIP uptake $(U)$ was plotted as a function of time. Using the linear portion of the graph, a linear regression was used to calculate $U_{R}$, DIP uptake rate per unit time. Each DIP uptake point was calculated as:

$$
U=\frac{\mathrm{Sa}_{\mathrm{cpm}}}{\mathrm{Eff}} \times \frac{1}{\mathrm{Sp}_{\mathrm{dpm}}} \times[P]
$$

where $U$ is DIP uptake at time $t=x$ of ${ }^{33} \mathrm{P}\left(\mu \mathrm{g} \mathrm{DIP}^{-1}\right)$, $\mathrm{Sa}_{\mathrm{cpm}}$ is the counts per minute (cpm) of the sample at time $t=x$, Eff is the efficiency of the Liquid Scintillation Analyzer used to count ${ }^{33} \mathrm{P}$, and $\mathrm{Sp}_{\mathrm{dpm}}$ is the disintegrations per minute $(\mathrm{dpm})$ of the ${ }^{33} \mathrm{P}$ spike added at time $t=0$, given as: 


$$
\mathrm{Sp}_{\mathrm{dpm}}=\mathrm{Sp}_{\mathrm{MBq}} \times 6.0 \times 10^{7}
$$

where $\mathrm{Sp}_{\mathrm{MBq}}$ is the radioactivity $(\mathrm{MBq})$ of the ${ }^{33} \mathrm{P}$ spike added at $t=0$. Eff is given by:

$$
\mathrm{Eff}=\left(\frac{\mathrm{St}_{\mathrm{cpm}}}{\mathrm{St}_{\mathrm{dpm}}}\right)
$$

where $\mathrm{St}_{\mathrm{cpm}}$ is the average cpm of the standards and $\mathrm{St}_{\mathrm{dpm}}$ is the dpm of the standards:

$$
\mathrm{St}_{\mathrm{dpm}}=\mathrm{St}_{\mathrm{MBq}} \times 6.0 \times 10^{7}
$$

where $\mathrm{St}_{\mathrm{MBq}}$ is the radioactivity of ${ }^{33} \mathrm{P}$ in the standards, in MBq.

DIP uptake was expressed as a chlorophyll-specific rate in $\mu$ g DIP $\mu \mathrm{g} \mathrm{chl} a^{-1} \mathrm{~h}^{-1}$. Concentrations of DIP in summer were occasionally at or below detection limits. Therefore, DIP values and their associated uptake rates at or less than the detection limit of $2 \mu \mathrm{g}$ DIP ${ }^{-1}$ were excluded from subsequent analyses.

\section{Statistical analysis}

Statistical analysis of physico-chemical data (surface water temperature, $\mathrm{pH}$, DIP, DOP, DIN molar DIP:DIN, chl $a$, secchi depth, bottom water DIP, DOP, DIN and molar DIP:DIN) and DIP uptake rates were conducted using PRIMER 6 (Clarke \& Gorley 2006). Changes in the variance of physico-chemical data and DIP uptake rate between sites $(1,2,3$ and 4$)$, and the mixing regime (stratified versus isothermal) were performed using repeated measures permutational analysis of variance (PERMANOVA; Anderson 2001) via the PERMANOVA+ add-on for Primer V6 (Anderson et al. 2008).

Classification and Regression Trees (CARTs; see De'ath \& Fabricius 2000 and Olden et al. 2008) were used for statistical analyses and to explain variation in DIP uptake with regards to physico-chemical data as explanatory variables via a univariate regression tree using the 'rpart' package in R v.3.14 (R Development Core Team 2011). CARTs are non-parametric and therefore ideal for modeling nonlinear data containing independent variables thought to interact in a hierarchical fashion. The tree is built by repeatedly partitioning the dataset into a nested series of mutually exclusive groups. The terminal nodes of the tree represent groups of samples with similar values of both response and explanatory variables. To calculate the overall importance of the independent variables in a decision tree, the CART analysis quantifies the improvement measure attributable to each vari- able in its role as a surrogate to the primary split. The values of these improvements are summed over each node and scaled relative to the best performing variable (Olden et al. 2008). Explanatory variables considered in our model included surface water temperature, surface DIP, surface DOP, surface DIN, bottom DIP, bottom DOP and bottom DIN. To avoid over-fitting the data, trees were set to a minimum terminal node count of 8 .

Finally, indicator phytoplankton species based on (1) the thermal regime and (2) the terminal nodes in the CART analysis were generated as per Dufrêne \& Legendre (1997) using the 'labdsv' package (Roberts 2010). The indicator index is the product of the relative abundance and relative frequency of occurrence of the species within a group. The index ranges from 0 through 100, with an index value of 0 equating to no occurrences and an index value of 100 equating to species counted on all instances within the group and no other group (De'ath 2002). Each index value is returned with a corresponding p-value. For brevity, we presented only those species considered statistically significant $(\mathrm{p}<0.05)$ with indicator values $>50$.

\section{DIP uptake in C. raciborskii laboratory cultures}

Laboratory studies were undertaken to measure DIP uptake rates by $C$. raciborskii, the dominant cyanobacterium in Lake Wivenhoe during summer (Burford \& O'Donohue 2006). A non-axenic monoculture of C. raciborskii (isolated from adjacent North Pine reservoir, Queensland, Australia) was grown in Jaworski's Media (JM; CCAP culture collection) in a growth cabinet at a constant temperature of $28^{\circ} \mathrm{C}$ under $12 \mathrm{~h}$ light:12 h dark cycles with illumination by fluorescent lights (Gro Light; $80 \mu \mathrm{mol}$ photons $\mathrm{m}^{-2} \mathrm{~s}^{-1}$ ). At the commencement of the study, a subsample of culture was used to inoculate $200 \mathrm{ml}$ of JM media without $\mathrm{P}$ addition. Sub-samples of $100 \mathrm{ml}$ were then removed and replaced with P-free JM Media on Days $0,5,11,18$ and 26 for DIP uptake experiments using the protocols outlined above. A portion of each sub-sample was fixed in Lugol's solution for measurement of cell concentrations, and another portion was filtered for DIP and chl a concentrations as outlined above. Half of the growth media was removed and the culture topped up with additional P-free JM media to ensure that DIP concentrations in the media progressively decreased. Cell densities at the commencement of the study were 51000 cells $\mathrm{ml}^{-1}$, and decreased with subsequent sub-culturing into P-free JM media. By 
the end of the culture period, cell densities were 11000 cells $\mathrm{ml}^{-1}$. P uptake experiments were performed as described for field samples.

\section{RESULTS}

\section{Lake physico-chemical parameters}

Variation in surface water temperature across all sites was comparable during the study period (ranging from $16.2^{\circ} \mathrm{C}$ in winter to $29.4^{\circ} \mathrm{C}$ in summer; Table 1). The water column was determined to be thermally stratified from September to February at Site 1, from August to February at Site 2, from August to March at Site 3 and from September to March at Site 4 (Fig. 2). For the purposes of this study, however, the lake was considered stratified only where all 4 sites consisted of a $\mathrm{d} T / \mathrm{d} z>0.5^{\circ} \mathrm{C} \mathrm{m} \mathrm{m}^{-1}$. Consequently, we classified the lake as summerstratified from September to February, and winterisothermal from March to August. Mean $( \pm$ SD) thermocline depth was $9.0 \pm 2.4,8.8 \pm 1.3,9.1 \pm 3.1$, 13.6 $\pm 5.2 \mathrm{~m}$ below the surface at Sites 1,2,3 and 4, respectively. Thermocline strength (i.e. maximum $\mathrm{d} T / \mathrm{d} z$ ) typically reached higher values upstream, with mean values of $0.99 \pm 0.54,1.18 \pm 0.85,0.67 \pm$ 0.33 and $0.67 \pm 1.6^{\circ} \mathrm{C} \mathrm{m}^{-1}$ recorded at Sites $1,2,3$ and 4 , respectively.

Secchi depth across all sites increased significantly in a downstream manner $\left(F_{3,25}=5.1, \mathrm{p}=0.005\right)$, with a mean of $1.2 \pm 0.3 \mathrm{~m}$ at Site 1 through $1.7 \pm 0.3 \mathrm{~m}$ at Site 4 (Table 1). Secchi depth, however, showed no significant variation between summer-stratified and winter-isothermal conditions $\left(F_{3,25}=1.6, \mathrm{p}=0.231\right)$, with differences in mean depths $<0.1 \mathrm{~m}$ at all sites. Surface $\mathrm{pH}$ was significantly higher $\left(F_{1,28}=3.7, \mathrm{p}=\right.$ $0.033)$ at all sites under summer-stratified conditions (mean $8.1 \pm 0.9$ to $8.5 \pm 0.7$ ) compared to winterisothermal conditions (mean $7.4 \pm 0.5$ to $7.9 \pm 0.2$ ). $\mathrm{pH}$ varied significantly between sites $\left(F_{3,28}=6.8, \mathrm{p}=\right.$ 0.002), and was elevated downstream at Sites 3 (mean $8.2 \pm 0.5)$ and $4(8.2 \pm 0.6)$ relative to upstream Sites 1 (mean $7.8 \pm 0.7$ ) and $2(7.7 \pm 0.9)$.

Surface DIP concentrations were typically higher during winter-isothermal conditions (mean $10.8 \pm$ $12.4 \mathrm{\mu g} \mathrm{l}^{-1}$ ) than during summer-stratified conditions $\left(4.8 \pm 5.9 \mathrm{\mu g} \mathrm{l}^{-1}\right)$ (Fig. 3a); however, since higher concentrations did not completely overlap with isothermal conditions, there was no significant difference between the 2 periods $\left(F_{1,28}=2.1, \mathrm{p}=0.146\right)$. Surface DIP concentrations varied significantly between sites $\left(F_{3,28}=6.6, \mathrm{p}=0.004\right)$ and generally decreased downstream, with means of $14.0 \pm 14.3,11.3 \pm 11.3,2.8 \pm$ 0.7 and $2.9 \pm 2.1 \mathrm{\mu g} \mathrm{l}^{-1}$ at Sites 1, 2, 3 and 4, respectively. Variation between summer-stratified and winter-isothermal surface DIP concentrations was considerable upstream but negligible downstream, where surface DIP concentrations were low yearround (Fig. 3a). Bottom water DIP concentrations were greater than surface water concentrations and varied little between summer-stratified and winter-

Table 1. Mean (SD) water quality parameters at the surface and bottom of each site over the study period. Surface refers to $3 \mathrm{~m}$ integrated surface samples and bottom samples were taken $1.5 \mathrm{~m}$ from the lake bottom. Win-iso: winter-isothermal, March to August; Sum-strat: summer-stratified, September to February. DIP: dissolved inorganic phosphorus; DOP: dissolved organic phosphorus; DIN: dissolved inorganic nitrogen. Secchi: Secchi depth

\begin{tabular}{|c|c|c|c|c|c|c|c|c|c|c|c|c|c|c|c|c|}
\hline & \multicolumn{4}{|c|}{$\longrightarrow$ Site $1 \longleftarrow$} & \multicolumn{4}{|c|}{ Site $2 \longrightarrow$} & \multicolumn{4}{|c|}{ - Site 3} & \multicolumn{4}{|c|}{ Site $4 \longrightarrow$} \\
\hline & \multicolumn{2}{|c|}{ Win-iso } & \multicolumn{2}{|c|}{ Sum-strat } & \multicolumn{2}{|c|}{ Win-iso } & \multicolumn{2}{|c|}{ Sum-strat } & \multicolumn{2}{|c|}{ Win-iso } & \multicolumn{2}{|c|}{ Sum-strat } & \multicolumn{2}{|c|}{ Win-iso } & \multicolumn{2}{|c|}{ Sum-strat } \\
\hline & Mean & $\mathrm{SD}$ & Mean & $\mathrm{SD}$ & Mean & $\mathrm{SD}$ & Mean & SD & Mean & $\mathrm{SD}$ & Mean & $\mathrm{SD}$ & Mean & $\mathrm{SD}$ & Mean & SD \\
\hline \multicolumn{17}{|l|}{ Surface } \\
\hline Temp $\left({ }^{\circ} \mathrm{C}\right)$ & 20.8 & 3.4 & 26.1 & 2.8 & 20.1 & 3.8 & 25.8 & 3.2 & 20.5 & 3.8 & 26.3 & 2.6 & 20.7 & 3.8 & 26.2 & 2.7 \\
\hline $\mathrm{pH}$ & 7.5 & 0.3 & 8.1 & 0.9 & 7.4 & 0.5 & 8.1 & 1.2 & 7.9 & 0.2 & 8.5 & 0.6 & 7.8 & 0.2 & 8.5 & 0.7 \\
\hline $\mathrm{DIP}\left(\mu \mathrm{g} \mathrm{P} \mathrm{l}^{-1}\right)$ & 21.4 & 16.6 & 7.8 & 9.5 & 15.4 & 13.2 & 6.4 & 7.1 & 2.8 & 0.4 & 2.9 & 0.9 & 3.8 & 2.4 & 2.5 & 0.6 \\
\hline $\mathrm{DOP}\left(\mu \mathrm{g} \mathrm{P}{ }^{-1}\right)$ & 22.2 & 10.6 & 10.8 & 2.7 & 17.9 & 8.8 & 8.2 & 2.2 & 11.6 & 2.0 & 8.6 & 3.3 & 9.9 & 4.7 & 8.8 & 4.0 \\
\hline DIN $\left(\mu g P^{-1}\right)$ & 81.6 & 64.7 & 21.4 & 4.9 & 70.0 & 79.9 & 21.4 & 9.1 & 14.5 & 12.1 & 16.8 & 7.6 & 86.0 & 68.9 & 15.8 & 6.7 \\
\hline DIN:DIP (molar) & 13.0 & 11.3 & 11.9 & 7.3 & 12.7 & 11.9 & 15.2 & 10.8 & 11.4 & 8.6 & 13.1 & 6.1 & 62.7 & 74.3 & 14.6 & 6.0 \\
\hline $\mathrm{Chl} \mathrm{a}\left(\mu \mathrm{g} \mathrm{P}^{-1}\right)$ & 12.7 & 7.3 & 22.4 & 11.5 & 15.2 & 9.5 & 19.9 & 10.4 & 14.4 & 3.8 & 14.6 & 7.3 & 8.1 & 2.7 & 11.2 & 4.6 \\
\hline Secchi (m) & 1.2 & 0.3 & 1.2 & 0.3 & 1.2 & 0.4 & 1.3 & 0.2 & 1.4 & 0.2 & 1.5 & 0.3 & 1.7 & 0.3 & 1.6 & 0.3 \\
\hline \multicolumn{17}{|l|}{ Bottom } \\
\hline $\mathrm{DIP}\left(\mu \mathrm{g} \mathrm{P}^{-1}\right)$ & 30.2 & 20.5 & 32.0 & 12.7 & 34.3 & 24.9 & 37.0 & 7.2 & 22.1 & 12.3 & 23.8 & 11.2 & 11.3 & 5.7 & 17.8 & 9.4 \\
\hline DOP $\left(\mu g \mathrm{P} \mathrm{l}^{-1}\right)$ & 6.1 & 5.6 & 75.0 & 114.3 & 9.6 & 4.7 & 89.0 & 92.0 & 7.3 & 6.0 & 75.8 & 81.1 & 12.7 & 22.4 & 21.8 & 52.3 \\
\hline DIN $\left(\mu g \mathrm{P}^{-1}\right)$ & 151.8 & 66.8 & 412.9 & 415.7 & 178.7 & 60.5 & 466.4 & 338.3 & 198.3 & 57.5 & 444.1 & 322.3 & 303.7 & 265.9 & 330.3 & 222.5 \\
\hline DIN:DIP (molar) & 15.6 & 8.7 & 24.4 & 17.7 & 20.1 & 15.7 & 25.9 & 13.8 & 25.2 & 16.0 & 48.0 & 50.2 & 64.3 & 59.5 & 49.6 & 46.6 \\
\hline
\end{tabular}




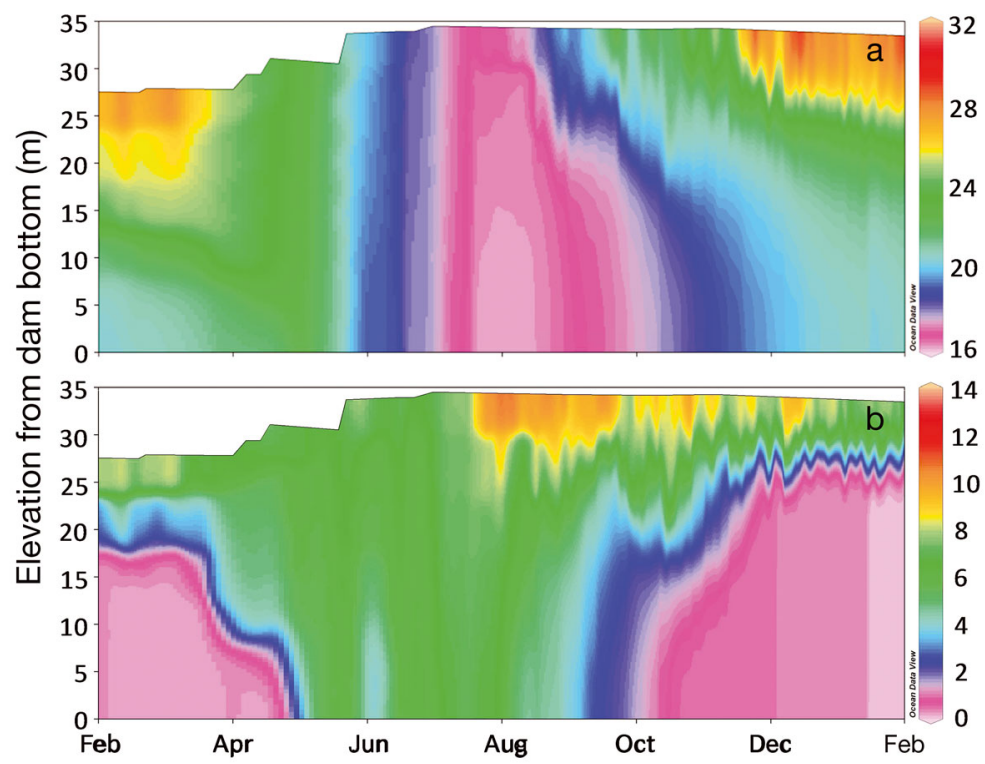

Fig. 2. (a) Water temperature $\left({ }^{\circ} \mathrm{C}\right)$ and (b) dissolved oxygen concentration $\left(\mathrm{mg} \mathrm{l}^{-1}\right)$ as a function of elevation from reservoir bottom (m) and time (months) at Site 4 over the 1 yr study period

(February 2009 to January 2010)
Sites 1 through 3, respectively). Bottom water DOP concentrations did not vary significantly between sites $\left(F_{3,28}=0.6, \mathrm{p}=0.598\right)$.

Surface water DIN concentrations did not vary significantly between summer-stratified and winter-isothermal conditions $\left(F_{1,28}=2.9, \mathrm{p}=\right.$ 0.072; Table 1). However, surface DIN concentrations varied significantly between sites $\left(F_{3,28}=\right.$ $2.8, \mathrm{p}=0.048$ ), largely due to differences in concentrations between Site 3 and the other sites. Mean surface DIN concentrations were $81.6 \pm$ $64.7,70.0 \pm 80.0,14.5 \pm 12.1$ and $86.0 \pm 68.9 \mu \mathrm{g}$ $1^{-1}$ during winter-isothermy, and $21.4 \pm 4.9,21.4$ $\pm 9.1,16.8 \pm 7.6$ and $15.8 \pm 6.7 \mu \mathrm{g} \mathrm{l}^{-1}$ during summer-stratification at Sites 1, 2, 3 and 4, respectively. Bottom water DIN did not vary significantly between sites $\left(F_{3,19}=1.2, \mathrm{p}=0.353\right)$ or between summer-stratified and winter-isothermal conditions $\left(F_{1,19}=1.8, \mathrm{p}=0.194\right)$. There was a wide range of molar DIN:DIP ratios in the surface water within each site and within each thermal regime, i.e. summer-stratified and win- isothermal conditions $\left(F_{1,28}=0.2, \mathrm{p}=0.981\right)$. Bottom water DIP varied significantly between sites $\left(F_{3,28}=7.2, \mathrm{p}=0.003\right)$ and generally decreased in a downstream direction, with means of $31.2 \pm 15.8,35.5 \pm 18.3,22.9 \pm$ 11.2 and $14.5 \pm 8.2 \mu \mathrm{g} \mathrm{l}^{-1}$ at Sites 1, 2, 3 and 4, respectively.

Surface DOP concentrations did not vary significantly between winter-isothermal (mean $14.1 \pm 6.9 \mathrm{\mu g} \mathrm{l}^{-1}$ ) and summer-stratified conditions $\left(9.3 \pm 3.1{\left.\mu \mathrm{g} \mathrm{l}^{-1}\right)}^{-1}\left(F_{1,28}=1.5, \mathrm{p}=0.259\right.\right.$; Table 1). Surface DOP concentrations varied significantly between sites $\left(F_{3,28}=7.7, \mathrm{p}=\right.$ 0.001 ) and decreased in a downstream direction, with mean concentrations of $16.0 \pm 9.2$, $13.5 \pm 8.2,10.1 \pm 3.0$ and $9.4 \pm 4.2 \mu \mathrm{g} \mathrm{l} \mathrm{l}^{-1}$ measured at Sites 1 through 4. Unlike surface water, bottom water DOP concentrations during summer-stratification were significantly $\left(F_{1,28}=5.6, \mathrm{p}=0.015\right)$ higher than those measured during winter-isothermy, with means of $74.7 \pm 83.0 \mu \mathrm{g} \mathrm{l}^{-1}$ and $6.9 \pm 12.2 \mathrm{\mu g} \mathrm{l}^{-1}$, respectively. During stratified conditions, concentrations commonly reached values in excess of $100 \mu \mathrm{g} \mathrm{l}^{-1}$, with a maximum concentration of $289 \mathrm{\mu g} \mathrm{l}^{-1}$ measured at Site 1 on 20 January. Mean bottom water DOP was noticeably lower at Site $4\left(26.8 \pm 43.0 \mu \mathrm{g} \mathrm{l}^{-1}\right)$ than the other sites $\left(44.1 \pm 88.4,45.7 \pm 71.5\right.$ and $40.8 \pm 66.0 \mu \mathrm{g} \mathrm{l}^{-1}$ at

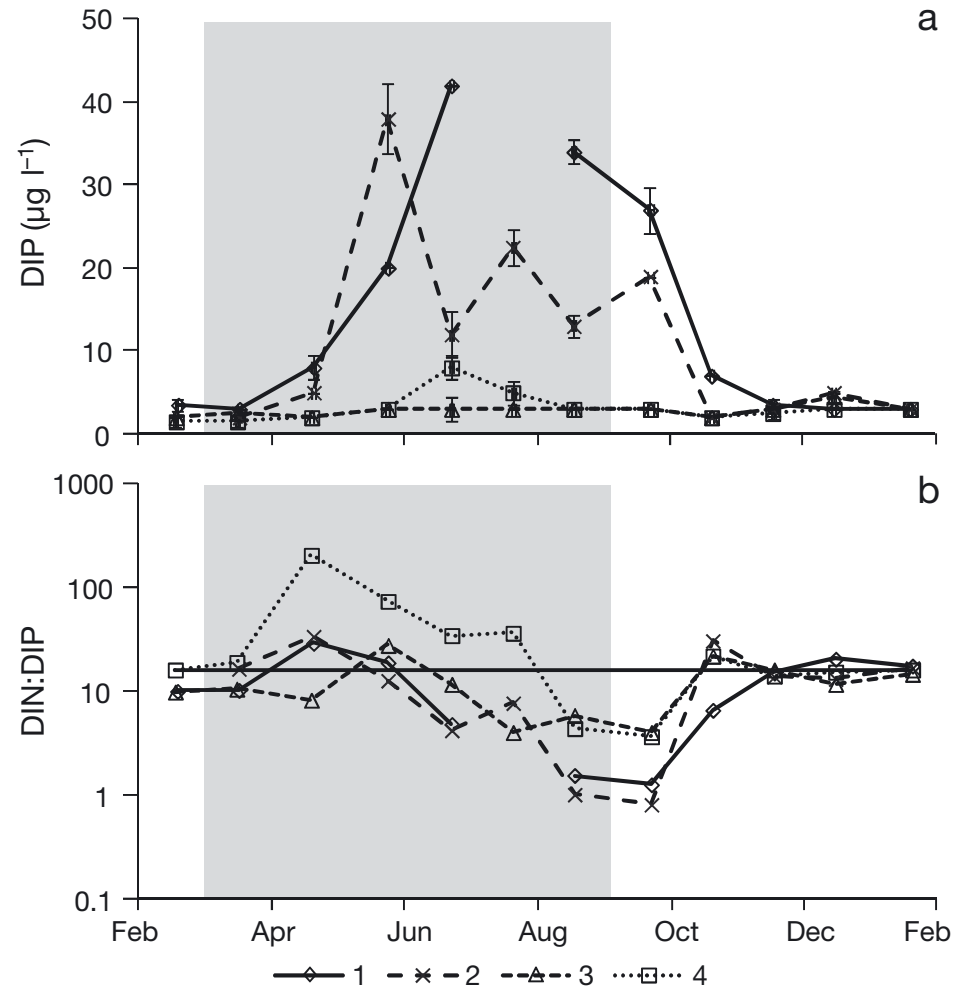

Fig. 3. (a) Mean ( \pm SD) surface dissolved inorganic phosphorus (DIP) concentrations ( $\mathrm{g} \mathrm{I} \mathrm{l}^{-1}$ ) and (b) surface dissolved inorganic nitrogen (DIN):DIP at Sites 1, 2, 3 and 4 over the study period (February 2009 to January 2010). Horizontal black line denotes 16:1 N:P Redfield Ratio; shaded area is the period of winter-isothermy. No sample was taken at Site 1 on 22 July 
ter-isothermal conditions, in both surface and bottom waters (Fig. 3b). DIN:DIP ratios in the surface waters ranged between lows of 0.8:1 (Site 2, 23 September) and highs of 207:1 (Site 4, 21 April); and in the bottom waters, lows of 7:1 (Site 1, 24 June) and highs of 178:1 (Site 4, 21 April). Overall, DIN:DIP ratios were highest at Site 4, predominantly during periods of winterisothermy.

\section{Lake phytoplankton}

The 10 most abundant species throughout the study period were all Cyanobacteria, with the filamentous species Planktolyngbya limnetica (Lemmermann) Komárková-Legnerová \& Cronberg, and the small colonial species Aphanocapsa spp. and Aphanothece spp. the most abundant numerically. Similarly, of the 10 species comprising the largest biovolume, 8 were Cyanobacteria, with filamentous C. raciborskii, Dolichospermum circinale (Rabenhorst ex Bornet \& Flahault) Wacklin, Hoffmann \& Komárek (previously Anabaena circinalis Rabenhorst ex Bornet \& Flahault) and other Dolichospermum spp. (previously Anabaena spp.) making up the largest biovolume. Specifically, C. raciborskii comprised up to $41 \%$ of the Cyanobacteria and $21 \%$ of the total biovolume during summer-stratified conditions. Cyanobacterial densities were highest during

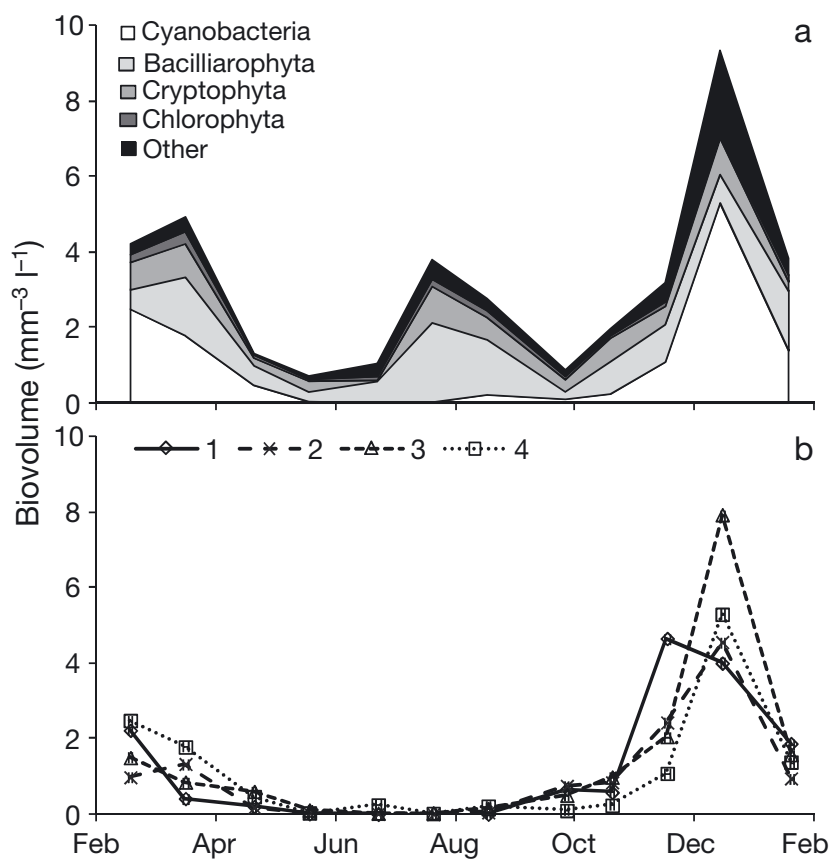

Fig. 4. Biovolumes of (a) dominant phytoplankton phyla at Site 4 and (b) total Cyanobacteria at Sites 1, 2, 3 and 4 over the study period (February 2009 to January 2010) summer-stratification and generally increased downstream (Fig. 4a). Maximum cell concentrations and biovolumes were 249000 cells $\mathrm{ml}^{-1}$ and $4.7 \mathrm{~mm}^{-3} \mathrm{l}^{-1}$, 348000 cells ml $\mathrm{m}^{-1}$ and $4.6 \mathrm{~mm}^{-3} \mathrm{l}^{-1}, 872000 \mathrm{cells} \mathrm{ml}^{-1}$ and $7.9 \mathrm{~mm}^{-3} \mathrm{l}^{-1}$ and 679000 cells ml $\mathrm{ml}^{-1}$ and $5.3 \mathrm{~mm}^{-3}$ $\mathrm{l}^{-1}$ at Sites 1 through 4 , respectively. The cyanobacteria Planktolyngbya limnetica, Aphanothece spp., Gloeothece spp., Myxobaktron spp. and A. circinalis and the chlorophytes Tetraedron spp. and Oocystis spp. were the strongest indicators of summer-stratified conditions.

Other than Cyanobacteria, many chlorophyte, cryptophyte and diatom species were identified in the lake during the study. They were, however, most abundant during winter-isothermy (Fig. 4b). It was under these conditions that the diatoms comprised the largest proportion of the assemblage biovolume, although Cyanobacteria remained the most numerically abundant. The numerically dominant genera were the diatom Monoraphidium spp., the cryptophyte Chroomonas spp. and an unidentified colonial chlorophyte, while the cryptophyte Cryptomonas spp. and the diatoms Aulacoseira spp. and Urosolenia spp. dominated by biovolume. The strongest indicators of winter-isothermy were the diatoms Melosira spp., Aulacoseira spp., Urosolenia spp. and the chlorophtyes Chlorella spp., Chlamydomonas spp. and Carteria spp.

Surface water chl a varied significantly with site $\left(F_{3,28}=5.0, \mathrm{p}=0.005\right)$ (Table 1$)$. Mean concentrations at Sites 1 through 4 were $18.0 \pm 10.7,17.3 \pm 9.7,14.5$ \pm 5.6 and $9.6 \pm 4.0 \mu \mathrm{g} \mathrm{chl} \mathrm{a} \mathrm{l}^{-1}$, respectively. Chl a did not vary significantly between summer-stratified and winter-isothermal conditions $\left(F_{1,28}=1.6, \mathrm{p}=0.231\right)$, with mean concentrations of $16.9 \pm 9.4 \mu \mathrm{g} \mathrm{l^{-1 }}$ during summer-stratified and $12.6 \pm 6.6 \mu \mathrm{g}^{-1}$ during winterisothermal conditions.

\section{DIP uptake rates}

Surface water DIP concentration and water temperature explained $50.3 \%$ of the variation in DIP uptake rate (Fig. 5). The branching sequence of the regression tree had DIP concentration as the primary split occurring at $4.75 \mu \mathrm{g}$ DIP $\mathrm{l}^{-1}$ and surface water temperature as secondary split at DIP concentrations below $4.75 \mu \mathrm{g} \mathrm{DIP}^{-1}$. The resulting regression tree ended with 3 terminal nodes at (1) DIP concentration $>4.75 \mu \mathrm{g} \mathrm{l}^{-1}$ with a mean DIP uptake rate of $0.4 \mu \mathrm{g}$ DIP $\mu$ g chl $a^{-1} \mathrm{~h}^{-1}$, (2) DIP concentration $<4.75 \mu \mathrm{g} \mathrm{l}^{-1}$ and temperature $<26.85^{\circ} \mathrm{C}$ with a mean DIP uptake rate of $3.3 \mu \mathrm{g}$ DIP $\mu \mathrm{g} \mathrm{chl} \mathrm{a}^{-1} \mathrm{~h}^{-1}$ and (3) DIP concen- 
tration $<4.75 \mu \mathrm{g} \mathrm{l} \mathrm{l}^{-1}$ and temperature $>26.85^{\circ} \mathrm{C}$ with a mean uptake rate of $5.6 \mu \mathrm{g}$ DIP $\mu \mathrm{g} \mathrm{chl} a^{-1} \mathrm{~h}^{-1}$. Further splits in the data based on the best alternative splits did not improve the model fit significantly.

A total of 13 species were identified as strong indicators of a terminal node in the CART analysis. The strongest indicators of terminal node 1 (DIP

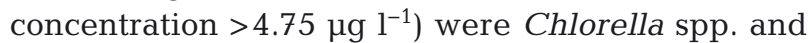
Melosira spp. At terminal node 2 (DIP concentration $<4.75 \mu \mathrm{g} \mathrm{l}^{-1}$ and temperature $<26.85^{\circ} \mathrm{C}$ ), the cyanobacteria Merismopedia punctata Meyen and Aphanocapsa spp. and the chlorophyte Fusola spp. were the strongest indicators. Finally, at terminal node 3 (DIP concentration $<4.75 \mu \mathrm{g} \mathrm{l^{-1 }}$ and temperature $>26.85^{\circ} \mathrm{C}$ ), Monoraphidium spp., Urosolenia spp. and 6 species of Cyanobacteria (Planktolyngbya minor (Geitler \& Ruttner) Komárek \& Cronberg, Gloeothece spp., Planktolyngbya limnetica, Pseudanabaena limnetica (Lemmermann) Komárek, C. raciborskii and Rhabdoderma spp.) were the strongest indicators

Across all sampling sites and times, specific DIP uptake rates in the surface waters were highest (but highly variable) at the lowest surface DIP concentrations, correlating with the transition of $4.75 \mu \mathrm{g} \mathrm{DIP} \mathrm{^{-1 }}$

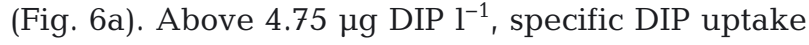
rates (excluding 1 outlier measured at Site 2 on 16 January 2009) were at their lowest, increasing linearly $\left(R^{2}=0.36\right)$ with surface water DIP concentrations (Fig. 6b). Specific DIP uptake rates varied significantly between sites $\left(F_{3,28}=9.0, \mathrm{p}=0.001\right)$ and between summer-stratified and winter-isothermal conditions $\left(F_{1,28}=5.8, \mathrm{p}=0.013\right)$. Mean specific DIP uptake rates were $4.0 \pm 2.8 \mu \mathrm{g}$ DIP $\mu \mathrm{g} \mathrm{chl} a^{-1} \mathrm{~h}^{-1}$ dur-

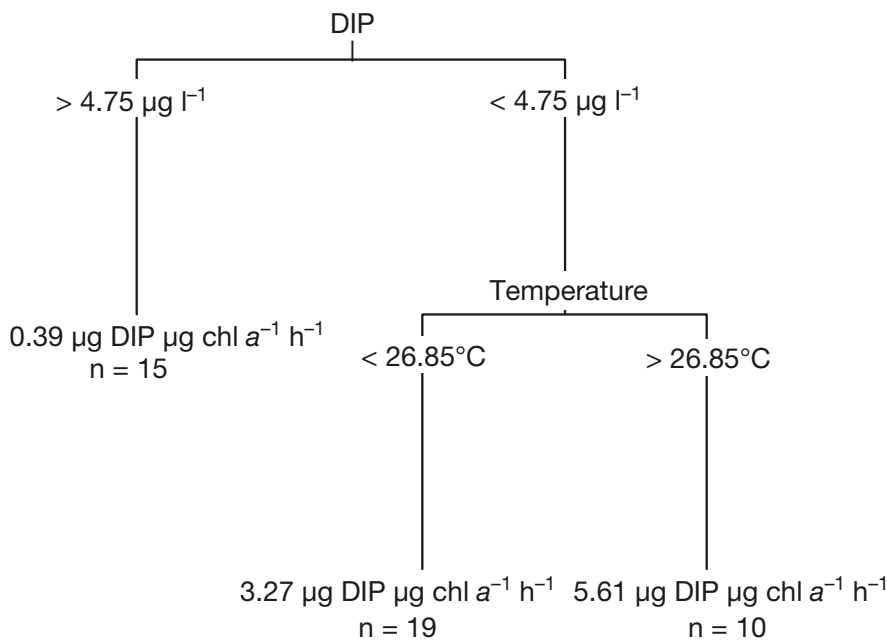

Fig. 5. Regression tree of surface dissolved inorganic phosphorus (DIP) uptake ( $\mu$ g DIP $\mu \mathrm{g} \mathrm{chl} \mathrm{a}^{-1} \mathrm{~h}^{-1}$; February 2009 to January 2010)

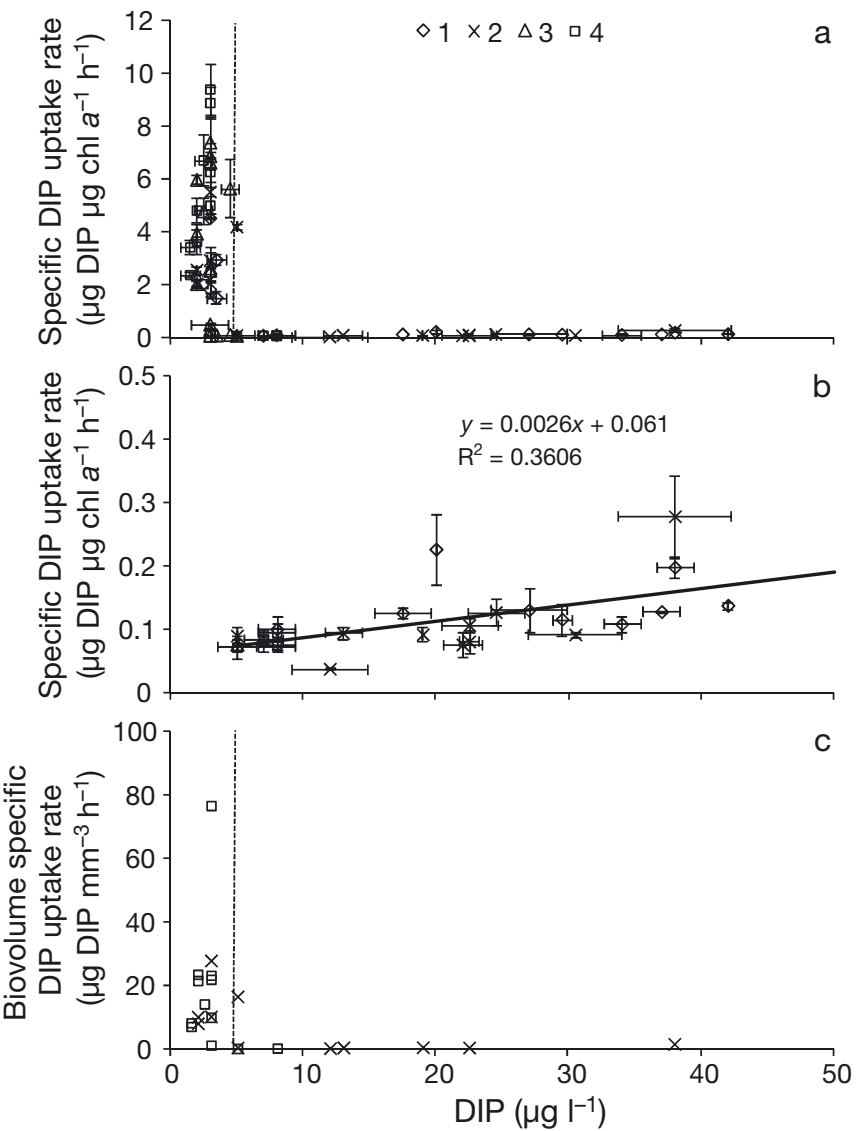

Fig. 6. Mean $( \pm \mathrm{SD})$ surface dissolved inorganic phosphorus (DIP) concentrations $\left(\mu \mathrm{g} \mathrm{l}^{-1}\right)$ versus mean specific DIP uptake ( $\mu$ g DIP $\mu \mathrm{g}$ chl $a^{-1} \mathrm{~h}^{-1}$ ) for (a) the entire data set (February 2009 to January 2010) and (b) at DIP concentrations above the 4.75 threshold (and excluding an outlier measured at Site 2 on 16 January 2009). Also shown are (c) mean surface DIP concentrations versus mean biovolumespecific DIP uptake $\left(\mu \mathrm{g}\right.$ DIP $\left.\mathrm{mm}^{-3} \mathrm{~h}^{-1}\right)$ at Sites 2 and 4 . Vertical dashed line denote $4.75 \mu \mathrm{g}$ DIP $\mathrm{l}^{-1}$ transition as demonstrated by the CART modeö in Fig. 5

ing summer-stratified conditions and $1.6 \pm 2.1 \mu \mathrm{g}$ DIP $\mu \mathrm{g} \operatorname{chl} a^{-1} \mathrm{~h}^{-1}$ during winter-isothermal conditions. Mean annual specific DIP uptake rates were typically higher downstream than upstream, i.e. $1.3 \pm 1.5,1.6$ $\pm 2.0,3.9 \pm 2.7$ and $4.3 \pm 3.2 \mu \mathrm{g}$ DIP $\mu \mathrm{g} \mathrm{chl} a^{-1} \mathrm{~h}^{-1}$ at Sites 1, 2, 3 and 4, respectively (Fig. 7). The 2 most upstream sites (Sites 1 and 2) exhibited higher monthly variation, whereas the downstream sites had consistently high uptake during the summerstratified period. Biomass-specific DIP uptake rates ( $\mu \mathrm{g}$ DIP $\mathrm{mm}^{-3} \mathrm{~h}^{-1}$ ) demonstrated the same relationship with DIP concentration as chl a specific DIP uptake rates (Fig. 6c).

Calculated TTs for DIP (i.e. the time taken by the phytoplankton to assimilate the DIP pool) were substantially shorter during summer-stratified conditions. Under these conditions, when surface DIP concentra- 


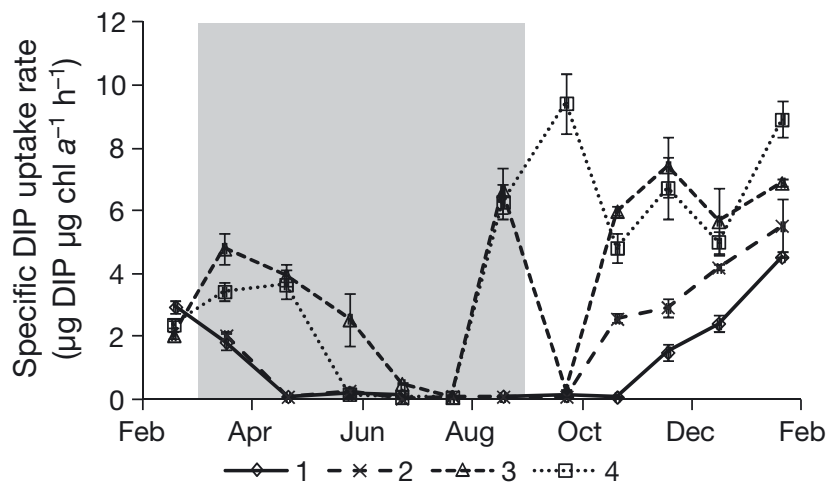

Fig. 7. Mean $( \pm \mathrm{SD})$ surface specific dissolved inorganic phosphorus (DIP) uptake rates ( $\mu$ g DIP $\mu g \mathrm{chl} a^{-1} \mathrm{~h}^{-1}$ ) across Sites 1, 2, 3 and 4 over the 1 yr study period (February 2009 to January 2010). Shaded area denotes period of winterisothermy

tions were commonly at or below detection limits $\left(<2 \mu \mathrm{g} \mathrm{l}^{-1}\right)$, TTs were on the order of minutes (as low as $2 \mathrm{~min}$ ). Conversely, under winter-isothermal conditions when DIP concentrations were higher, TTs were as long as $22 \mathrm{~h}$.

\section{DIP uptake in C. raciborskii laboratory cultures}

C. raciborskii monocultures that were progressively starved of DIP increased their specific DIP uptake rates in a manner resembling MichaelisMenten kinetics with respect to time: $y=2.417 x /$ $(3.144+x)$ (Fig. 8). During this time, specific DIP uptake rates went from $0.06 \mu \mathrm{g}$ DIP $\mu \mathrm{g} \mathrm{chl} a^{-1} \mathrm{~h}^{-1}$ on Day 0 of the experiment to $2.2 \mu \mathrm{g}$ DIP $\mu \mathrm{g} \mathrm{chl} a^{-1} \mathrm{~h}^{-1}$ by Day 26, corresponding to a 36 fold increase in specific DIP uptake rate. The theoretical maximum

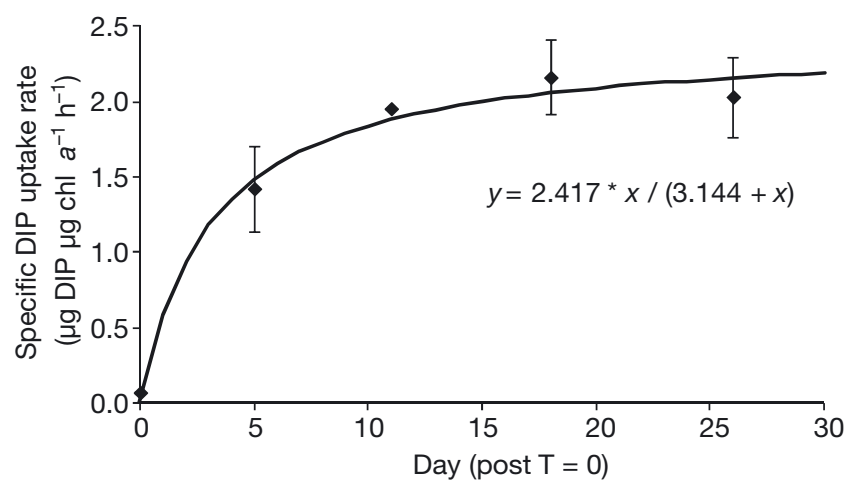

Fig. 8. Lab-based dissolved inorganic phosphorus (DIP) uptake ( $\mu \mathrm{g}$ DIP $\mu \mathrm{g} \mathrm{chl} \mathrm{a}^{-1} \mathrm{~h}^{-1}$ ) in cultures of Cylindrospermopsis raciborskii. Cultures were placed in P-free media and sampled every 3 to $5 \mathrm{~d}$ between 7 October and 2 November 2011. Error bars denote \pm 1 SD for 3 replicates.

NB: sample on Day 12 consists of only 1 replicate $(n=1)$ uptake rate was $2.4 \mu \mathrm{g}$ DIP $\mu \mathrm{g} \mathrm{chl} a^{-1} \mathrm{~h}^{-1}$. Measured DIP concentrations were less than the detection limit $\left(2 \mu \mathrm{g}^{-1}\right)$ throughout the duration of the experiment.

\section{DISCUSSION}

This study showed that specific uptake rates of DIP by phytoplankton were higher during the summerstratified period when DIP concentrations were at their lowest, i.e. $<4.75 \mu \mathrm{g}$ DIP $\mathrm{l}^{-1}$. Furthermore, we identified an increase in DIP uptake rates in response to progressive DIP-starvation in culture studies of $C$. raciborskii, one of the dominant Cyanobacteria in Lake Wivenhoe (Burford \& O'Donohue 2006, Muhid 2011). This study also represents the first attempt to explain variation in DIP uptake with the physicochemical data by multivariate means, with $50.3 \%$ of the variation in DIP uptake rate explained by surface water DIP concentration and temperature. Our study also shows that the best indicator species of elevated DIP uptake rates, based on species abundance, were primarily Cyanobacteria, including C. raciborskii.

Specific DIP uptake rates in Lake Wivenhoe were substantially elevated under summer-stratified conditions. Summer-stratified specific DIP uptake rates were $4.2 \mu \mathrm{g}$ DIP $\mu \mathrm{g} \mathrm{chl} a^{-1} \mathrm{~h}^{-1}$, and winter-isothermal specific DIP uptake rates $1.6 \mu \mathrm{g}$ DIP $\mu \mathrm{g}$ chl $a^{-1} \mathrm{~h}^{-1}$. Using carbon to chl a ratios of ranging from 1:27 to 1:67 as with Riemann et al. (1989), our reported uptake rates were equivalent to 88 to $218 \mu \mathrm{mol} \mathrm{P} \mathrm{mg}$ $\mathrm{C}^{-1} \mathrm{~d}^{-1}$ during summer-stratified conditions and 33 to

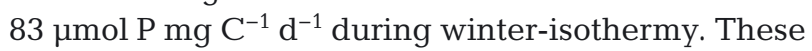
rates were comparable to those reported in the literature, which were as high as 236 (Istvànovics et al.

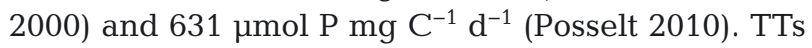
(i.e. DIP concentration divided by DIP uptake rate) during winter were on the order of hours to days, while during summer were in the order of minutes. Rapid TTs found in this study were consistent with a study of a stratified P-limited North American lake, showing TTs of 5 to 8 min (Nowlin et al. 2007), and a study of 53 P-limited North American lakes showing TTs of 1 to 10 min (Hudson et al. 2000).

Specific DIP uptake rates in Lake Wivenhoe were largely explained (50.3\% of the variation) by both surface water DIP and surface water temperature. Although such a relationship has not yet been published in the literature, both variables have precedence in explaining the rate of DIP uptake by phytoplankton. External DIP concentration has often been associated with enhanced DIP uptake rate, where rates substantially increase as external DIP concen- 
trations fall below the said threshold (e.g. Aubriot et al. 2011). In the present study, surface water DIP concentration had a strong effect on DIP uptake rate where phytoplankton community DIP uptake kinetics increased substantially at a concentration below $4.75 \mu \mathrm{g} \mathrm{DIP}^{-1}$. Despite this, there was considerable variability in the uptake rates below this threshold. DIP concentration was therefore shown to be a necessary (but not the only) variable explaining variation in DIP uptake rate. Much of this variation in DIP uptake rates below concentrations of $4.75 \mathrm{\mu g} \mathrm{l}^{-1}$ was explained in the model by surface water temperature, with $26.85^{\circ} \mathrm{C}$ appearing to be an important threshold. Changes in temperature have substantial effects on phytoplankton physiology, including affecting enzyme activity (e.g. alkaline phosphatase; Healey \& Hendzel 1979), as well as nitrogen uptake rates (Reay et al. 2001) and P uptake rates (Rhee \& Gotham 1981).

Transition from low to high DIP uptake rates at DIP concentrations of $4.75 \mathrm{\mu g} \mathrm{l}^{-1}$ indicates a change between low-and high-affinity DIP uptake in Lake Wivenhoe. Above $4.75 \mathrm{\mu g} \mathrm{l}^{-1}$, DIP is taken up via the Pit system. This process is energetically inexpensive as DIP passively crosses the transmembrane electrochemical gradient into the cell (Jansson 1988, Vershinina \& Znamenskaya 2002). Conversely, at concentrations below $4.75 \mu \mathrm{g}$ DIP $\mathrm{l}^{-1}$, Pho regulon genes are induced, encoding and upregulating the high-affinity pstS and sphX P-binding proteins of the repressible Pst system (Jansson et al. 1988, Vershinina \& Znamenskaya 2002, Orchard et al. 2009). These high-affinity binding proteins bind and transport DIP into the cell, enabling species to assimilate DIP at nanomolar levels (Aubriot \& Bonilla 2012). As highaffinity uptake is energetically expensive, species will use the low-affinity Pit system by default, and the Pst system will only be initiated (in those that possess it) when DIP cannot be taken up at concentrations sufficient to ensure their survival.

Diatoms, cryptophytes and chlorophytes dominated the phytoplankton biovolume under winterisothermal conditions in Lake Wivenhoe. Winterisothermal conditions were largely characterized by lower water temperatures, elevated surface water DIP concentrations, and reduced DIP uptake rates. Furthermore, as water temperatures cooled in autumn and the water column mixed, accumulated DIP in the bottom waters was mixed into surface waters, resulting in increased surface water DIP. Such a relationship is typical of seasonally stratified systems and has been previously reported in Lake Wivenhoe (Muhid 2011) as well as other neighbour- ing lakes (Burford \& O'Donohue 2006). These cooler and well-mixed waters during winter create more suitable growing conditions for species such as diatoms and cryptophytes with lower temperature optima (Paerl \& Huisman 2009). Water column instability during isothermal conditions is also ideal for diatoms to reduce sinking out of the euphotic zone, as occurs during summer-stratified conditions (Istvánovics et al. 1994, Paerl \& Huisman 2009). The dominance of diatoms, cryptophytes and chlorophytes during this period, as well as diatom and chlorophytes being indicator species, appears to reflect the low measured DIP uptake rates, and is consistent with the low-affinity uptake mode as described by Michaelis-Menten kinetics (Dugdale \& Goering 1967).

Cyanobacteria principally dominated the phytoplankton numerically and by biovolume under summer-stratified conditions in Lake Wivenhoe. They also proved the best indicator species under such conditions. Summer-stratified conditions were characterized by higher water temperatures and Pdepauperate conditions. These conditions are ideal for Cyanobacteria, many of which possess a high temperature optima and the ability of high-affinity DIP uptake (Robarts \& Zohary 1987, Burford \& Davis 2011). We also found 8 Cyanobacteria indicative of the elevated DIP uptake rate in Lake Wivenhoe as denoted by the terminal nodes in the CART analysis. Of these species, C. raciborski (Istvànovics et al. 2000) has been reported as having the ability of highaffinity DIP uptake, while other numerically dominant species such as Dolichospermum spp. were not revealed as an indicator to possess the ability. It is possible that other cyanobacterial species either identified as indicator species of elevated DIP uptake rates, or other dominant species, also possess the capacity for high-affinity uptake. The results of the field and laboratory studies nonetheless suggest that DIP depletion is promoting high-affinity DIP uptake under P-limited conditions. Possession of a highaffinity uptake system may provide a competitive advantage over others in which the process is either absent or weakly developed (Istvànovics et al. 2000, Posselt et al. 2009).

Diatoms and chlorophytes comprised several of the species strongly associated with elevated DIP uptake. Although not numerically abundant, the presence of Urosolenia spp., Fusola spp. and Monoraphidium spp. were indicative of high DIP uptake as seen in terminal nodes 2 and 3 of the CART analysis. While none of these species are known to possess high-affinity DIP uptake genes, some eukary- 
otic algae, e.g. the coccolithophorid Emiliania huxleyi (Riegman et al. 2000) and the diatom Thalassiosira pseudonana (Dyhrman et al. 2012), possess the capacity for high-affinity DIP uptake. This, however, is the exception rather than the rule. It is therefore unlikely that the species in our study possess the capacity for high-affinity DIP uptake, although temperature may be important. Shafik et al. (1997) and Mitrovic et al. (2010) surmised that the diatom Cyclotella meneghiniana Kützing is selected for under warmer surface water temperatures $\left(>23^{\circ} \mathrm{C}\right)$.

Unexplained variation in the DIP uptake model may also be due factors such as antecedent $\mathrm{P}$ exposure. Aubriot et al. (2011), for instance, studied adaptive uptake behaviour of lake phytoplankton in response to short term fluctuations in DIP availability. They found that the phytoplankton had different threshold values for incorporation of DIP into the polyphosphate pool depending on their recent history of exposure to fluctuations in DIP concentrations. This led to considerable variation in rates of DIP uptake. Moreover, the capacity of a species to store $\mathrm{P}$ as polyphosphate bodies may be a factor. Internal $P$ stores have been demonstrated to be superior to that of external $\mathrm{P}$ concentrations as $\mathrm{P}$ limitation indicators (Jansson 1988). This stands to reason as phytoplankton have the ability to store $\mathrm{P}$ in excess as polyphosphate bodies, to be used during periods where external DIP is limited (Thingstad et al. 1993). Consequently, there may be a lag in the up-regulation of inducible genes encoding those involved in increasing DIP uptake affinity, thus making internal $\mathrm{P}$ stores a better predictor of environmental DIP shortage.

Although surface water temperature was shown to explain much of the variation in DIP uptake rates

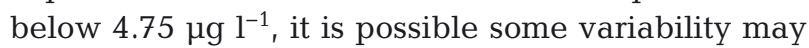
also be the result of analytical issues relating to measurement of DIP. Current analytical methods provide incomplete information as DIP is only a proxy for bioavailable P. The acid-molybdate colourimetric method used in our study is the method typically used for measuring DIP in aquatic systems. However, this method has been suggested to overestimate, by also measuring a portion of acid-labile organic P compounds (e.g. Hudson et al. 2000, Hudson \& Taylor 2005). Nonetheless, the same relationship observed between DIP concentration and DIP uptake rate can be seen between DIP concentration and radioactivity in dpm. Therefore, the patterns observed are real despite this apparent analytical problem.
As Cyanobacteria dominance is largely temperature dependent, cyanobacterial blooms can be expected to increase in duration and geographical range as global warming causes water temperatures to rise and stratification to increase $\left(\mathrm{O}^{\prime} \mathrm{Neil}\right.$ et al. 2012). This can already be seen with species such as C. raciborskii originating from the subtropical latitudes spreading northward and southward (Wiedner et al. 2007). Their spread will lead to drastic changes in physical, chemical and biological properties of the newly invaded systems. Changes could include an increase in turbidity, leading to a suppression of aquatic macrophytes, thus destroying habitat for many invertebrates and fish species in invaded systems (Paerl et al. 2001, Paerl \& Huisman 2009). Higher temperature optima in Cyanobacteria and adaptations including high-affinity uptake (e.g. Vershinina \& Znamenskaya 2002, Orchard et al. 2009), $\mathrm{N}$-fixation (e.g. Burford et al. 2006), and the use of organic P through alkaline phosphatase (MuñozMartín et al. 2011) will give them the ability to outcompete the natural phytoplankton assemblage should nutrients become limiting. Furthermore, many Cyanobacteria possess toxin-producing genes such as cylindrospermopsin (CYN) and paralytic shellfish poison (PSP; Istvànovics et al. 2000, Burford \& Davis 2011). These toxins are a major threat to freshwater systems for drinking water, irrigation, fishing and recreational purposes (Carmichael 2001, Paerl et al. 2001). CYN and PSP may cause serious problems in animals and humans, including liver, kidney and intestine damage, gastroenteritis, fever, rashes, neurological impairment and death (Hitzfeld et al. 2000, Carmichael 2001, Bláha et al. 2009).

Active high-affinity DIP uptake kinetics are different from those described by Michaelis-Menten modeled uptake kinetics. This has implications for the use of plankton ecosystem models to predict phytoplankton responses to nutrients. These models have changed little since the 1970s and continue to use, for example, Michaelis-Menten kinetics to describe nutrient uptake and subsequent growth (Franks 2009). As a result, the ability of these models to predict nutrient dynamics and phytoplankton concentration or biomass remains relatively poor (Arhonditsis \& Brett 2004). Models can, however, provide a method of hypothesis testing (Franks 2009), and in the case of our study could be used to determine whether the high-affinity DIP uptake under low DIP availability affects model predictions of phytoplankton biomass or other measures.

In conclusion, our study demonstrates that surface DIP concentration and water temperature may be 
used to predict DIP uptake rates. Additionally, we determined species (primarily Cyanobacteria) that are indicative of conditions leading to elevated DIP uptake. Finally, we demonstrated a succession in phytoplankton dominance, from cyanobacteria in summer-stratified conditions to diatoms, cryptophytes and chlorophytes during winter-isothermy. Diatom and chlorophyte dominance during winterisothermy could be largely explained by cooler water temperatures and water instability due to isothermal conditions, while cyanobacterial dominance during summer-stratified conditions was linked to elevated DIP uptake rates. We validated the link between DIP uptake and cyanobacterial dominance by demonstrating that the dominant cyanobacterium, C. raciborskii, increased its DIP uptake rate as it became progressively starved of P. Our findings indicate that rapid DIP scavenging via high-affinity DIP uptake is advantageous under DIP-depauperate conditions common during summer-stratified conditions. Highaffinity uptake will therefore contribute to cyanobacterial dominance in P-depauperate lakes, and contribute to the switch from diatom, cryptophyte, chlorophyte dominance to cyanobacterial dominance during stratified periods in seasonally P-depauperate lakes.

Acknowledgements. We thank Robert Rolls for statistical advice, Stephen Faggotter, Matthew Whittle, Christin Sawstrom, Carolyn Polson, Lisa Galbraith, Graeme Curwen and Alistair Grinham for assistance with sample collection, staff and students at the Australian Rivers Institute, Griffith University for technical advice, staff at Seqwater for providing water quality data, and Queensland Health and the Queensland Department of Environment and Resource Management for nutrient analyses. This work was funded by an Australian Research Council Linkage (LP0776375), Seqwater, and the Australian Rivers Institute, Griffith University.

\section{LITERATURE CITED}

Anderson MJ (2001) A new method for non-parametric multivariate analysis of variance. Austral Ecol 26:32-46

Anderson MJ, Gorley RN, Clarke KR (2008) PERMANOVA+ for PRIMER: guide to software and statistical methods. PRIMER-E, Plymouth

APHA (American Public Health Association) (1995) Standard methods for the examination of water and wastewater, 19th edn. APHA, Washington, DC

- Arhonditsis GB, Brett MT (2004) Evaluation of the current state of mechanistic aquatic biogeochemical modeling. Mar Ecol Prog Ser 271:13-26

> Aubriot L, Bonilla S (2012) Rapid regulation of phosphate uptake in freshwater cyanobacterial blooms. Aquat Microb Ecol 67:251-263

Aubriot L, Wagner F, Falkner G (2000) The phosphate uptake behaviour of phytoplankton communities in eutrophic lakes reflects alterations in the phosphate supply. Eur J Phycol 35:255-262

Aubriot L, Bonilla S, Falkner G (2011) Adaptive phosphate uptake behaviour of phytoplankton to environmental phosphate fluctuations. FEMS Microbiol Ecol 77:1-16

Bar-Yosef Y, Sukenik A, Hadas O, Viner-Mozzini Y, Kaplan A (2010) Enslavement in the water body by toxic Aphanizomenon ovalisporum, inducing alkaline phosphatase in phytoplanktons. Curr Biol 20:1557-1561

Bláha L, Babica P, Maršálek B (2009) Toxins produced in cyanobacterial water blooms - toxicity and risks. Interdiscip Toxicol 2:36-41

Burford MA, Davis TW (2011) Physical and chemical processes promoting dominance of the toxic cyanobacterium Cylindrospermopsis raciborskii. Chin J Oceanology Limnol 29:883-891

Burford MA, O'Donohue MJ (2006) A comparison of phytoplankton community assemblages in artificially and naturally mixed subtropical water reservoirs. Freshw Biol 51:973-982

Burford MA, McNeale KL, McKenzie-Smith FJ (2006) The role of nitrogen in promoting the toxic cyanophyte Cylindrospermopsis raciborskii in a subtropical water reservoir. Freshw Biol 51:2143-2153

> Burford MA, Johnson SA, Cook AJ, Packer TV, Taylor BM, Townsley ER (2007) Correlations between watershed and reservoir characteristics, and algal blooms in subtropical reservoirs. Water Res 41:4105-4114

Carmichael WW (2001) Health effects of toxin-producing cyanobacteria: "the CyanoHABs". Hum Ecol Risk Assess 7:1393-1407

Clarke KR, Gorley RN (2006) Primer v6: user's manual. Primer-E, Plymouth

Coles JF, Jones RC (2000) Effect of temperature on photosynthesis-light response and growth of four phytoplankton species isolated from a tidal freshwater river. J Phycol 36:7-16

- Cotner JB, Wetzel RG (1992) Uptake of dissolved inorganic and organic phosphorus compounds by phytoplankton and bacterioplankton. Limnol Oceanogr 37 : 232-243

De'ath G (2002) Multivariate regression trees: a new technique for constrained classification analysis. Ecology 83: 1103-1117

> De'ath G, Fabricius KE (2000) Classification and regression trees: a powerful yet simple technique for ecological data analysis. Ecology 81:3178-3192

> Donald KM, Scanlan DJ, Carr NG, Mann NH, Joint I (1997) Comparative phosphorus nutrition of the marine cyanobacterium Synechococcus WH7803 and the marine diatom Thalassiosira weissflogii. J Plankton Res 19: 1793-1813

Dufrêne M, Legendre L (1997) Species assemblages and indicator species: the need for a flexible asymemetrical approach. Ecol Monogr 67:345-366

> Dugdale RC, Goering JJ (1967) Uptake of new and regenerated forms of nitrogen in primary productivity. Limnol Oceanogr 12:196-206

Dyhrman ST, Haley ST (2006) Phosphorus scavenging in the unicellular marine diazotroph Crocosphaera watsonii. Appl Environ Microbiol 72:1452-1458

Dyhrman ST, Jenkins BD, Rynearson TA, Saito MA and others (2012) The transcriptome and proteome of the diatom Thalassiosira pseudonana reveal a diverse phosphorus stress response. PLoS ONE 7:e33768 
Ebina J, Tsutsui T, Shirai T (1983) Simultaneous determination of total nitrogen and total phosphorus in water using peroxodisulphate oxidation. Water Res 17:1721-1726

Franks PJS (2009) Planktonic ecosystem models: perplexing parameterizations and a failure to fail. J Plankton Res 31: 1299-1306

Gibbes BR, Barry ME, Collecutt GR, Lemckert CJ, Udy J, Lockington DA (2009) Preliminary modelling of hydrodynamics of purified recycled water inputs to Lake Wivenhoe. In: Anderssen RS, Braddock RD, Newham LTH (eds) 18th world IMACS congress and MODSIM international congress on modelling and simulation. The Modelling and Simulation Society of Australia and New Zealand, Cairns

Harke MJ, Berry DL, Ammerman JW, Gobler CJ (2012) Molecular response of the bloom-forming cyanobacterium, Microcystis aeruginosa, to phosphorus limitation. Microb Ecol 63:188-198

Healey FP, Hendzel LL (1979) Fluorometric measurement of alkaline phosphatase activity in algae. Freshw Biol 9: 429-439

Hitzfeld BC, Hoger SJ, Dietrich DR (2000) Cyanobacterial toxins: removal during drinking water treatment, and human risk assessment. Environ Health Perspect 108 (Suppl 1):113-122

Hötzel G, Croome R (1999) A phytoplankton methods manual for Australian freshwaters. Land and Water Resources Research and Development Corporation, Canberra

Hudson JJ, Taylor WD (1996) Measuring regeneration of dissolved phosphorus in planktonic communities. Limnol Oceanogr 41:1560-1565

> Hudson JJ, Taylor WD (2005) Rapid estimation of phosphate at picomolar concentrations in freshwater lakes with potential application to P-limited marine systems. Aquat Sci 67:316-325

Hudson JJ, Taylor WD, Schlindler DW (2000) Phosphate concentrations in lakes. Nature 406:54-56

Hwang S, Havens KE, Steinman AD (1998) Phosphorus kinetics of planktonic and benthic assemblages in a shallow subtropical lake. Freshw Biol 40:729-745

Istvánovics V, Padisák J, Pettersson K, Pierson DC (1994) Growth and phosphorus uptake of summer phytoplankton in Lake Erken (Sweden). J Plankton Res 16:1167-1196

Istvánovics V, Shafik HM, Présing M, Juhos J (2000) Growth and phosphate uptake kinetics of the cyanobacterium, Cylindrospermopsis raciborskii in flowthrough cultures. Freshw Biol 43:257-275

Jansson M (1988) Phosphate uptake and utilization by bacteria and algae. Hydrobiologia 170:177-189

Jansson M (1993) Uptake, exchange, and excretion of orthophosphate in phosphate-starved Scenedesmus quadricauda and Pseudomonas K7. Limnol Oceanogr 38: 1162-1178

Jansson M, Olsson H, Petterson K (1988) Phosphatases: origin, characteristics and function in lakes. Hydrobiologia 170:157-175

Jeffrey SW, Welschmeyer NA (1997) Spectrophotometric and fluorometric equations in common use in oceanography. In: Jeffrey SW, Mantoura RFC, Wright SW (eds) Phytoplankton pigments in oceanography: guidelines to modern methods. UNESCO, Paris, p 597-615

Karl DM, Tien G (1992) MAGIC: a sensitive and precise method for measuring dissolved phosphorus in aquatic environments. Limnol Oceanogr 37:105-116
McAlice B (1971) Phytoplankton sampling with the Sedgwick-Rafter cell. Limnol Oceanogr 16:19-28

Mitrovic SM, Hitchcock JN, Davie AW, Ryan DA (2010) Growth responses of Cyclotella meneghiniana (Bacillariophyceae) to various temperatures. J Plankton Res 8: $1217-1221$

Moore LR, Ostrowski M, Scanlan DJ, Feren K, Sweetsir T (2005) Ecotypic variation in phosphorus-acquisition mechanisms within marine picocyanobacteria. Aquat Microb Ecol 39:257-269

Muhid P (2011) The role of nutrients with respect to promoting phytoplankton growth and species composition in a subtropical reservoir. PhD dissertation, Griffith University, Brisbane

Muñoz-Martín MA, Mateo P, Leganés F, Fernández-Piñas F (2011) Novel cyanobacterial bioreporters of phosphorus bioavailability based on alkaline phosphatase and phosphate transporter genes of Anabaena sp. PCC 7120. Anal Bioanal Chem 400:3573-3584

> Nowlin WH, Davies J, Mazumder A (2007) Planktonic phosphorus pool sizes and cycling efficiency in coastal and interior British Columbia lakes. Freshw Biol 52:860-877

O'Neil JM, Davis TW, Burford MA, Gobler CJ (2012) The rise of harmful cyanobacteria blooms: the potential roles of eutrophication and climate change. Harmful Algae 14: 313-334

Olden JD, Lawler JJ, Poff NL (2008) Machine learning methods without tears: a primer for ecologists. Q Rev Biol 83: 171-193

Orchard ED, Webb EA, Dyhrman ST (2003) Characterization of phosphorus-regulated genes in Trichodesmium spp. Biol Bull 205:230-231

> Orchard ED, Webb EA, Dyhrman ST (2009) Molecular analysis of the phosphorus starvation response in Trichodesmium spp. Environ Microbiol 11:2400-2411

- Paerl HW, Huisman J (2009) Climate change: a catalyst for global expansion of harmful cyanobacterial blooms. Environ Microbiol Rep 1:27-37

Paerl HW, Fulton RS, Moisander PH, Dyble J (2001) Harmful freshwater algal blooms, with an emphasis on cyanobacteria. Sci World J 1:76-113

Posselt AJ (2010) Are nutrients the key driver in promoting dominance of toxic cyanobacterial blooms in a sub-tropical reservoir? PhD thesis, Griffith University, Brisbane

Posselt AJ, Burford MA, Shaw G (2009) Pulses of phosphate promote dominance of the toxic cyanophyte Cylindrospermopsis raciborskii in a subtropical water reservoir. J Phycol 45:540-546

Reay DS, Priddle J, Nedwell DB, Whitehouse MJ, EllisEvans JC, Deubert C, Connelly DP (2001) Regulation by low temperature of phytoplankton growth and nutrient uptake in the Southern Ocean. Mar Ecol Prog Ser 219: 51-64

Rhee GY, Gotham IJ (1981) The effect of environmental factors on phytoplankton growth: temperature and the interactions of temperature with nutrient limitation. Limnol Oceanogr 26:635-648

Riegman R, Stole W, Noordeloos AAM, Slezak D (2000) Nutrient uptake and alkaline phosphatase (EC 3:1:3:1) activity of Emaliania huxleyi (Prymnesiophyceae) during growth under $\mathrm{N}$ and $\mathrm{P}$ limitation in continuous cultures. J Phycol 36:87-96

Riemann B, Simonsen P, Stensgaard L (1989) The carbon and chlorophyll content of phytoplankton from various nutrient regimes. J Plankton Res 11:1037-1045 
Ritchie RJ, Trautman DA, Larkum AWD (2001) Phosphate limited cultures of the cyanobacterium Synechococcus are capable of very rapid, opportunistic uptake of phosphate. New Phytol 152:189-201

Robarts RD, Zohary T (1987) Temperature effects on photosynthetic capacity, respiration and growth rates of bloom-forming cyanobacteria. NZ J Mar Freshw Res 21: 391-399

Roberts DW (2010) labdsv: ordination and multivariate analysis for ecology. R package version 1.4-1. http:// cran.r-project.org/web/packages/labdsv/index.html

Scheffer M, Rinaldi S, Gragnani A, Mur LR, van Nes EH (1997) On the dominance of filamentous cyanobacteria in shallow turbid lakes. Ecology 78:272-282

Shafik HM, Herodek S, Vôrôs L, Présing M, Kiss KT (1997) Growth of Cyclotella meneghiniana Kutz. I. Effects of temperature, light and low rate of nutrient supply. Ann Limnol 33:139-147

Tanaka T, Rassoulzadegan F, Thingstad TF (2004) Orthophosphate uptake by heterotrophic bacteria, cyanobacteria, and autotrophic nanoflagellates in Villefranche Bay, northwestern Mediterranean: vertical, seasonal, and short-term variations of the competitive relationship for phosphorus. Limnol Oceanogr 49:1063-1072

Tanaka T, Henriksen P, Lignell R, Olli K, Seppala J, Tammi-

Editorial responsibility: Hugh MacIntyre,

Halifax, Nova Scotia, Canada nen T, Thingstad TF (2006) Specific affinity for phosphate uptake and specific alkaline phosphatase activity as diagnostic tools for detecting phosphorus-limited phytoplankton and bacteria. Estuar Coast 29:1226-1241

R Development Core Team (2011) R: a language and environment for statistical computing. R Foundation for Statistical Computing, Vienna

Thingstad TF, Skjoldal EF, Bohne RA (1993) Phosphorus cycling and algal-bacterial competition in Sandsfjord, western Norway. Mar Ecol Prog Ser 99:239-259

Vershinina OA, Znamenskaya LV (2002) The Pho regulons of bacteria. Microbiology 71:497-511

Vidal M, Duarte CM, Agusti S, Gasol JM, Vaque D (2003) Alkaline phosphatase activities in the central Atlantic Ocean indicate large areas with phosphorus deficiency. Mar Ecol Prog Ser 262:43-53

Wagner F, Falkner R, Falkner G (1995) Information about previous phosphate fluctuations is stored via an adaptive response of the high-affinity phosphate uptake system of the cyanobacterium Anacystis nidulans. Planta 197: $147-155$

Wiedner C, Rucker J, Bruggemann R, Nixdorf B (2007) Climate change affects timing and size of populations of an invasive cyanobacterium in temperate regions. Oecologia 152:473-484

Submitted: September 12, 2013; Accepted: March 10, 2015 Proofs received from author(s): June 3, 2015 